\title{
MEMORIES OF STAN ROWE
}

\section{DON GAYTON, 23 Robson St., Nelson BC V1L 5A9, E-mail: <d.gayton@netidea.com>}

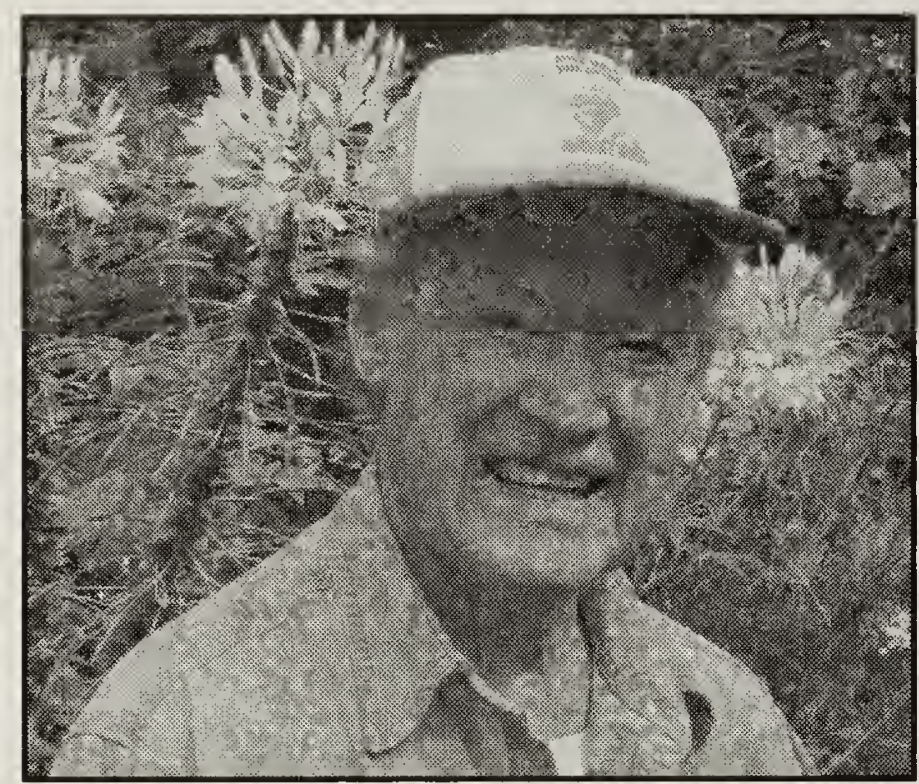

Stan Rowe in 2003

P. Jonker

My connections with Stan Rowe (19182004) amount to a couple of momentary flickers in the course of his long and illustrious life, but those brief encounters were significant. Perhaps that is one measure of greatness; the ability to make even small moments seem large.

I first met Stan in 1975, when I was a new and lowly graduate student in the University of Saskatchewan's Department of Plant Ecology. He was not my major professor, but I turned to him often for advice. His quiet presence was reassuring as I stumbled about, learning the ropes of a new role, a new discipline, and a new country. At first, "Ecology" was just a vague buzzword to me, but in my chats with Stan, I grew to see the profound meaning and importance of the term.

My own Master's thesis was a tortuous project on the grazing response of certain native grasses. In the course of defining the research problem, setting up hypotheses, testing them, rejecting false positives and experiencing the buzzing complexity of natural systems, I learned a great deal about the scientific process. That learning came to be the major outcome of the thesis project. As I wrote up the thesis, I happened to be reading Bertolt Brecht's wonderful play, Galileo. In the play, the character Galileo has brilliant literary insights on the scientific process, so I put a quote from the play as a frontispiece to the thesis:

"Perhaps they are clouds, perhaps they are sunspots, but before we assume they are sunspots, which would be most opportune for us, let us rather assume they are fishes' tails. Yes, we will question everything, and everything once again. And, we shall advance not in seven-league boots, but at a snail's pace. And what we find today we shall strike from the record tomorrow, and only write it again when we have once more discovered it. And what we wish to find, if we find it, we shall regard with especial distrust...."

When it came time for my thesis defence, seven distinguished professors, one after another, passed judgment on the Brecht quote, demanding that it be removed, saying a piece of literature had no place in a scientific document. I felt like a heretic at the Inquisition. Stan happened to be the last, eighth professor to pass judgment, and all eyes turned to him. Stan said three words, which I shall forever remember, and be forever grateful for. "The quote stays," he said, quietly. There was no further discussion; the quotation was accepted and we moved on to other issues. 
Stan had not only defended my right to idiosyncrasy; he had also lent support to my pathetic attempt to marry science and the arts, a theme that loomed large in Stan Rowe's own life.

There was much that I didn't learn about Stan in those early days, but we picked up the threads of friendship again many years later, when Stan moved to New Denver, British Columbia, and I was living in nearby Nelson. The story of his connection to New Denver slowly unfolded: conscientious objector during World War II, sent to teach high school in the Japanese internment camp in New Denver, returning to live in that isolated mountain town after his retirement. I had been a conscientious objector during the Vietnam War (a far less daunting stance), so this provided a mostly unspoken bond between us.

Periodically I would pass through New Denver and stop at the cozy little Rowe house on Josephine Street for a chat. Canada's foremost ecologist, he was mostly content to stay home, out of the limelight. Once I convinced him to give a talk at an annual Botany BC conference ("Botany" in this case was an acronym, standing for "botanical organization to achieve nothing yearly"). When he asked me what topic he should speak on, I said the field was open: boreal forest ecology, park management, environmental conservation-he could choose from any of his many fields of expertise. When he rose to speak at the conference, his topic surprised us all: it was an impassioned plea for more women in the fields of natural resource management and ecology.

Another time, I convinced him to give a reading with me in Nelson. I read a few snatches from The Wheatgrass Mechanism. ${ }^{1}$ but the main attraction was Stan, who read from his fine work, Home Place. ${ }^{2}$ At one point in Stan's reading the text referred to singing, and to illustrate the point, Stan sang a lovely Irish ballad, a capella. He was right on key, and the audience loved it.

Writing was a big part of Stan's later years, and he focused on ecological theory. He was one of the early voices urging for ecosystem management on a landscape scale, long before it came into vogue. And he extended the Gaia theory, critiquing our obsession with living organisms. In a well-known paper, What on Earth is Life?, Stan argued convincingly that the spark of life lies not in the organism, the cell or the nucleus, but rather in the physical environment that sustains the organism. ${ }^{3}$

Stan was active in a local New Denver writing club. A club member shared with me one of Stan's Haiku poems that demonstrated Stan's sly and delightful humor:

\section{A bear on the trail!}

The philosopher runs

Just like everyone else.

In rereading one of Stan's papers recently, I ran across this resonant phrase: "the landscape as an object of moral concern." That sums up perfectly what much of Stan's life was about - gently prodding us to recognize the centrality of the environment in our moral universe. He will be missed.

1. GAYTON, D. 1990. The Wheatgrass Mechanism. Fifth House Publishers, Saskatoon.

2. ROWE, S. 1990. Home Place: Essays on Ecology. NeWest Publishers, Edmonton.

3. ROWE, S. 2001. What on earth is life: an ecological view. Ecosystem Health 7 (3):141 